\title{
FLOUTING MAXIM IN THE SPONGEBOB MOVIE: SPONGE ON THE RUN
}

\author{
Ramadhanisya $^{1}$, Sri Hartati \\ ${ }^{1,2}$ Gunadarma University, Jl. Margonda Raya No. 100, Depok 16424, Jawa Barat \\ Corresponding Author(S): nisyamars@gmail.com
}

\begin{abstract}
:
Maxims are rules for determining whether the speaker is being cooperative in a conversation or not. When a speaker refuses to be cooperative during a conversation, this is known as flouting of maxim. This research focuses on flouting maxims uttered by the characters in The SpongeBob Movie: Sponge on the Run. The objective of this research is to identify the types of flouting maxims contained in this movie. The researcher used the descriptive qualitative method to analyze the data. The result of this research showed that the researcher found 41 utterances that flout the maxim in The SpongeBob Movie: Sponge on the Run. There are flouting the maxim of quality ( 6 data), flouting the maxim of quantity (16 data), flouting the maxim of relevance (15 data), and flouting the maxim of manner ( 9 data). The number of utterances and the number of flouting maxims used are different because one utterance may include more than one flouting maxim.
\end{abstract}

Keywords:

Cooperative

Principle, Flouting maxim, Movie

\section{INTRODUCTION}

People will meet and communicate with others in their daily lives. This communication activity is connected to the use of language. Language is the primary form of communication. According to Hamilton (2007:5), communication is the act of people expressing their opinions, ideas, and thoughts with one another in a way that others can understand. Communication is said to be smooth when both parties understand each other and there are no misunderstandings. Language as a form of communication which is done by people to communicate with others to express their needs -request, information, or services, we can say as speakers must consider the persons they are talking to as listeners (Santoso, 2015: 183). To be cooperative, both the speaker and the hearer must follow the cooperative principle to make a good conversation.

The cooperative principle is a part of pragmatics. The cooperative principle consists of four maxims. There is the maxim of quality, the maxim of quantity, the maxim of relevance, and the maxim of manner.

There may be problems, misunderstandings, or misinterpretations in communication that occur in everyday life, and there must be difficulties or misunderstandings that occur in 
everyday life because the hearer does not recognize what the speaker is saying. In other words, communication between the speaker and the hearer is not always easy.

When a speaker is not cooperative during a conversation, it is considered a flouting of the maxim. When the speaker says anything that is believed to be false, he/she flouts the quality maxim. When the speaker says more or less in providing information, he/she flouts the quantity maxim. When the speaker says an irrelevant response to the conversation's topic, he/she flouts the relevance principle. When the speaker says anything ambiguous or unclear, he/she flouts the maxim of manner. In our daily lives, sometimes people flout the maxim. For example:

A: "These elementary school children draw very well, don't you think?"

B: "Yeah, they are very creative."

C: $\quad$ "Yeah right, they are clever. But I can draw a better future as long as I'm with you."

In the example above, the answer "B is normal. Meanwhile, the answer " $\mathrm{C}$ " flouts the maxim of quantity because he/she gives too much information to the question asked.

Pragmatics is a branch of linguistics that studies the meaning of an utterance. Leech (1983:x), explained that pragmatics can be usefully defined as the study of how utterances have meanings in different situations. Levinson (1983:21) also stated that pragmatics is the study of the relationships between language and meaning that characterizes every account of language comprehension. Knowing the meanings of the words uttered and their grammatical connections isn't enough to understand an utterance. Making inferences that relate what is stated to what is assumed or what has already been expressed is required to understand an utterance.

To summarize, pragmatics is the study of the relationship between utterances and the contexts in that they are delivered. The context in question is a factor outside of the utterance that influences the meaning of the utterance.

Furthermore, Grice in Thomas (1995) stated a flout happens when a speaker consciously ignores a maxim at the level of what is said with the intent of conveying an implicature. Flouting can occur in four of the maxim's sub-principles, they are flouting the maxim of quality, flouting the maxim of quantity, flouting the maxim of relevance, and flouting the maxim of manner.

Table 1 Types of Flouting Maxim (Grice, 1995 in Thomas)

\begin{tabular}{ll}
\hline Types of Flouting Maxim & \multicolumn{1}{c}{ Description } \\
\hline Flouting the maxim of quality & $\begin{array}{l}\text { when the speaker says something which is blatantly untrue or for } \\
\text { which he or she lacks adequate evidence }\end{array}$ \\
Flouting the maxim of relevance & $\begin{array}{l}\text { a flout of the maxim of quantity occurs when a speaker blatantly } \\
\text { gives more or less information than the situation requires } \\
\text { response or observation which is very obviously irrelevant to the } \\
\text { topic in hand (e.g. by abruptly changing the subject, or by overtly } \\
\text { failing to address the other person's goal in asking a question) }\end{array}$
\end{tabular}


Commonly, in conversation, flouting of the maxim has easily to found because the communication between the speaker and the hearer is not always smooth. Flouting of maxim occurs when the speaker deliberately ceases to apply the maxims to persuade their listeners to infer the hidden meaning behind the utterances; that is, the speakers employ implicature (Levinson in Ibrahim, et. al., 2018: 82). This research only focused on the analysis of the flouting maxim uttered by all characters in The SpongeBob Movie: Sponge on the Run. The present study was addressed to answer the following research question: what are the flouting of maxim uttered by all characters in The SpongeBob Movie: Sponge on the Run.

\section{METHOD}

According to Creswell (2009:3), research designs are plans and procedures for research that span the decisions from board assumptions to detailed methods of data collection and analysis. It means that the research design assists researchers in gathering data as a reference in collecting data, analyzing data, and presenting data. To cAs a result, the researchers choose this approach to analyze and describes the data from the characters in The SpongeBob Movie: Sponge on the Run.

SpongeBob SquarePants is one of the most popular cartoons in Indonesia which has been broadcast and dubbed throughout the world. SpongeBob SquarePants is a comedy cartoon that reflects human behavior as well, including language.

The researchers analyzed the data by using a descriptive qualitative method in this research. Descriptive analysis means to analyze the data which describes the research based on the fact taken from the movie. The research deals with a research procedure that generates descriptive data in the sentence forms, specifies in simple sentences (Santoso, 2018: 5). The source of this data was the movie. According to it, 41 utterances flout the maxim. The utterances then were analyzed, categorized, and grouped into types of flouting maxim by Grice in Thomas (1995). The findings were presented using tables and textual descriptions.

\section{RESULTS AND DISCUSSION}

From 41 utterances, the researchers have found four types of flouting maxims in The SpongeBob Movie: Sponge on the Run. They are flouting the maxim of quality, flouting the maxim of quantity, flouting the maxim of relevance, and flouting the maxim of manner. In this chapter, the data will be explained using Grice's theory of flouting maxims.

Table 2 Types of Flouting Maxim

\begin{tabular}{lll}
\hline No. & Types of Flouting Maxim & Number \\
\hline 1. & Flouting Maxim of Quality & 6 \\
2. & Flouting Maxim of Quantity & 16 \\
3. & Flouting Maxim of Relevance & 15 \\
4. & Flouting Maxim of Manner & 9 \\
\hline Total & & 46 \\
\hline
\end{tabular}




\section{Flouting the Maxim of Quality \\ Data 1}

Flouting the maxim of quality occurs when a speaker says something that is not true but does not mislead the hearer. In this scene, Mr. Krabs, Sandy, and Squidward were watching the news on TV until they realized that SpongeBob and Patrick had been arrested at the Poseidon Kingdom for attempting to reclaim Gary, SpongeBob's pet snail. The news said that Otto's car had been seized after being pursued by police from the Poseidon Kingdom. Sandy asked "Mr. Krabs what happened to Otto?" and Mr. Krabs replied, "Well, he took an automated vacation!"

From the utterance above, when answering Sandy's question, Mr. Krabs had flouted the maxim of quality by not answering according to the facts. Because Otto is far too coldhearted to be the owner of the automatic restaurant at the Krusty Krab. Therefore, Mr. Krabs dumped Otto. He did not give Otto an automatic vacation. According to the theory from Grice in Thomas (1995:67) when a speaker says anything false or for which he or she lacks facts, he or she is flouting the quality maxim. Mr. Krabs flouts the maxim of quality because he does not give truthful information according to the facts Sandy.

\section{Data 2}

Otto: "No, seriously. We decided to go in a different direction. You're fired." Mr. Krabs: "What?"

Otto: "Don't make me call security."

In this scene, Sandy gives Mr. Krabs an automated restaurant owner named Otto and Mr. Krabs accepts the robot. Because the robot is not human, it only speaks and follows out all the instructions as instructed according to the program that Sandy has made. Otto can make cold and heartless decisions like firing people because it doesn't have a heart. Mr. Krabs was confused. Because suddenly, the robot took over as the owner of the Krusty Krab. Otto said, "Don't make me call security."

From the utterance above, Otto had flouted the maxim of quality when responding to Mr. Krabs question. Otto gave the wrong information because it could not possibly fire Mr. Krabs and call security. Mr. Krabs is the real owner and doesn't have any faults. Otto is too heartless to be the owner of the automatic restaurant at the Krusty Krab. According to the theory from Grice in Thomas (1995:67) when a speaker states anything false or for which he or she lacks appropriate facts, he or she is flouting the quality maxim. Otto flouted the maxim of quality by saying things that were not based on facts.

\section{Data 3}

SpongeBob: "Patrick, the zombies are swarming!"

Patrick: "They're gonna eat our brains!"

In this scene, SpongeBob and Patrick have a mission to free the zombies' souls in The Inferno Saloon. El Diablo, the leader of the zombies, came and the zombies began to gather. When SpongeBob and Patrick go in there, they were very scared. SpongeBob told Patrick "Patrick, the zombies are swarming!" and Patrick replied, "They're gonna eat our brains!"

From the utterance above, Patrick had flouted the maxim of quality when responding to SpongeBob's fear. Patrick thought the zombies would eat their brains. But the zombies were gathered to dance, not to eat their brains. According to the theory from Grice in Thomas (1995:67) when a speaker states anything false or for which he or she lacks 
appropriate facts, he or she is flouting the quality maxim. Patrick flouted the maxim of quality by saying things that were untrue about the zombies.

\section{Flouting the Maxim of Quantity \\ Data 4}

Flouting the maxim of quantity occurs when a speaker provides too little or too much information to the hearer. In this scene, Squidward came in the morning to Krusty Krab for work. He thought that he came earlier than SpongeBob, so he could feel peace for a while. But SpongeBob suddenly surprises him by appearing beside the cashier table to greet him by saying "Good morning, Squidward! And isn't it a lovely morning?". Squidward replied, "Nope. Not talking to you. I'm especially not getting involved in any of your nonsense today. I always end up with the wrong end of the stick."

From the utterance above, Squidward had flouted the maxim of quantity when answering SpongeBob's greeting. He answers SpongeBob's greeting like that because he hates him. For Squidward, SpongeBob is very annoying. Squidward always has bad luck when he is near SpongeBob. It is in line with the theory from Grice in Thomas (1995:69), flouting the maxim of quantity occurs when a speaker blatantly provides more or less information than the situation requires. Squidward flouted the maxim of quantity because he gave too much information when answering SpongeBob's greeting.

\section{Data 5}

SpongeBob: "Wait, what? You're gonna replace me with a robot? Don't do it!" Sandy: "No, silly, that's gonna happen anyway. This is something much more innovative and start-uppy."

When SpongeBob was working giving krabby patties to the customers, Sandy visits the Krusty Krab and want to introduce Mr. Krabs to the robot restaurant owner she created. Sandy tells SpongeBob that in the future everyone will use machines. SpongeBob is afraid that the robot will replace his job at the Krusty Krab. SpongeBob asked Sandy "Wait, what? You're gonna replace me with a robot? Don't do it!". Sandy replied, "No, silly, that's gonna happen anyway. This is something much more innovative and start-uppy." From the utterance above, Sandy had flouted the maxim of quantity when answering SpongeBob's question. It was enough for SpongeBob if Sandy answered "No, silly that's not gonna happen anyway." Sandy gave too much information about the robot and SpongeBob does not ask about the robot's advantages. It is in line with the theory from Grice in Thomas (1995:69) when a speaker blatantly gives more or less information than the conditions needs, this is called a flouting maxim of quantity. Sandy flouted the maxim of quantity because she gave too much information when answering SpongeBob's question.

\section{Flouting the Maxim of Relevance \\ Data 6}

Flouting the maxim of relevance occurs when a speaker is irrelevant to the topic discussed. In this scene, Chancellor was called by King Poseidon to see his skin as smooth as a baby's. King Poseidon always thinks that the beauty of his skin is the most important thing to amaze his people. King Poseidon asked "Ha! I owe it to my subjects to look fabulous, don't you think?" And Chancellor replied, "There are other obligations, sire. Like ruling and stuff. Let's see... I need your signature on these taxes, decrees, this here declaration of war, and my paycheck." 
From the utterance above, Chancellor had flouted maxim of relevance when answering King Poseidon's question. Chancellor changed the topic of the conversation. Chancellor called by King Poseidon to see if his skin was as smooth as a baby's. King Poseidon always thinks that the beauty of his skin is the most important thing to amaze his people. Chancellor changed the topic of the conversation by discussing the required signatures on several documents and the Chancellor's salary slip. Unfortunately, King Poseidon does not care about that because he only focuses on his skin. According to the theory from Grice in Thomas (1995:70) the flouting maxim of relevance occurs when a response or observation is unrelated to the topic being discussed (e.g. by suddenly changing the subject, or blatantly failing to answer the other person's purpose in asking a question). Chancellor flouted the maxim of relevance because he changed the topic of the conversation.

\section{Data 7}

Patrick: "Buck up. It's not over yet, SpongeBob."

SpongeBob: "It sure feels over. And crappy."

Patrick: "Just saying there's two sides to every coin."

In this scene, SpongeBob and Patrick are in prison because they will be executed by King Poseidon for trying to take the snail, Gary, that was used as face cream by King Poseidon. SpongeBob feels sad because he failed to take Gary from king Poseidon and bring Patrick into this trouble. Patrick calmed SpongeBob by saying "Buck up. It's not over yet, SpongeBob." SpongeBob replied "It sure feels over. And crappy." And then Patrick replied, "Just saying there's two sides to every coin."

From the utterance above, Patrick had flouted the maxim of relevance while answering SpongeBob's response because Patrick had changed the topic of the conversation. Patrick's answer changes the topic of conversation while he was calming SpongeBob. Patrick suddenly changed the topic to the courage coin that Sage had given him. It is in line with the theory from Grice in Thomas (1995:70) the flouting maxim of relevance occurs when a response or observation is irrelevant to the topic being discussed (e.g. by suddenly changing the subject, or blatantly failing to answer the other person's purpose in asking a question). It means, Patrick flouted the maxim of relevance because he changed the topic of conversation.

\section{Flouting the Maxim of Manner}

Flouting maxim of manner occurs when the speaker says something unclear, ambiguous, or disorderly. In this scene, Plankton devises Evil Plan 3087 to steal Mr. Krabs' secret Krabby Patty recipe. Plankton plans on taking the Krabby Patty secret formula recipe at night. Plankton asked Karen "What's wrong with another evil plan?" and Karen answered, "Oh, nothing, it's just we're running out of room on the Wall of Failure."

From the utterance above, Karen had flouted maxim of manner when answering Plankton's question about the Evil Plan. Karen said, "Oh, nothing, it's just we're running out of room on the Wall of Failure." Plankton did not realize what Karen meant. It turns out they are documentation photos of Plankton's failure to steal the secret recipe. This is related to Grice's theory in Thomas (1995:71) the flouting maxim of manner occurs when a speaker deliberately flouts a rule of manners by stating something unclearly, not being orderly, or applying ambiguity. Karen provides an ambiguous answer to Plankton. It means Karen flouted the maxim of manner. 


\section{CONCLUSION}

In this research, the researcher found all of the types of flouting maxims in The SpongeBob Movie: Sponge on the Run. They are flouting the maxim of quality, flouting the maxim of quantity, flouting the maxim of relevance, and flouting the maxim of manner. According to the results, the total number of flouting maxims used from 41 utterances was 46 . Because an utterance may contain more than one flouting maxim, the number of utterances and the number of flouting maxims used are different. First, the flouting maxim of quality occurs 6 times. Second, the flouting maxim of quantity occurs 16 times. Third, the flouting maxim of relevance occurs 15 times. The last, the flouting maxim of manner occurs 9 times.

The researcher hopes this research can be a motivation for all readers or researchers who are interested in flouting maxim. The researcher also hopes for the next researcher can use this research as an example or reference.

\section{REFERENCE}

Creswell, J. W. (2009). Research design: Qualitative, quantitative, and mix methods approaches (3rd ed.). California: SAGE Publication, Inc.

Hamilton, C. (2007). Communicating for results: A guide for business and the professions (8th ed.). California: Wadsworth Publishing.

Ibrahim, Z., Arifin, M. B., \& Setyowati, R. (2018). The flouting of maxim in the se7en movie script. Ilmu Budaya: Jurnal Bahasa, Sastra, Seni dan Budaya, 2(1), 81-94.

Leech, G. N. (1983). Principles of pragmatics. England: Longman Group Limited.

Levinson, S. C. (1983). Pragmatics. Cambridge: Cambridge University Press.

Santoso, D. A. A. (2015). The effects of reading habit and vocabulary mastery towards student's speaking skill. DEIKSIS, 6(03), 181-188.

Santoso, D. A. A. (2019). The Translation Result Evaluation Of Non-Standard English Simple Sentences (African American Vernacular English) Into Indonesian In The Novel Entitled The Help By Kathryn Stockett. Scope: Journal of English Language Teaching, 3(1), 1-12.

Thomas, J. A. (1995). Meaning in interaction: An introduction to pragmatics. New York: Routledge. 